\title{
Promises and Challenges with Organization 2.0 Paradigm
}

\author{
L. El Bassiti and R. Ajhoun
}

\begin{abstract}
In a hyper-competitive global economy, the ability to adapt quickly to a turbulent environment that determines the future of organizations. To be able to adapt, an organization must, of course, be innovative and attractive. By looking at the principles of adaptability, we will thus also lift the veil on the necessary conditions for the creation of intensely collaborative and creative organizations, where the employees are fully involved. Those are the challenges that face the organizations of the $21^{\text {st }}$ century.

This paper focuses on five challenges we consider the most relevant for any future organization that seeks sustain advantage. For each of these challenges, we sought an inspiration that may offer a useful analogy to stimulate and guide our thinking. Next, we selected three companies whose success has been the most consistent throughout the $20^{\text {th }}$ century and which have provided innovative solutions to our problems. After having briefly presented them, we highlighted some of the lessons learned from them. We finish by describing design features of the organization 2.0.
\end{abstract}

Index Terms-Collaboration and innovation, digital natives, organization 2.0 and adaptation, web 2.0 and social technologies.

\section{INTRODUCTION}

The movement of transformation of organizations is still in progress with various economic developments, since the industrial economy to the economy of knowledge of today. This movement, in the last few years, was carried by two major evolutions: The first one concerns the rapid technological advancements. So, with the advent of social and Web 2.0 technologies, new usages of information, knowledge sharing culture, new practices and new individual, collective and organizational behaviors have emerged. The second evolution is related to the new generation of young graduates new to the job market today, called Digital Natives, youth who are attracted by these technologies, eager to find simply and quickly the right information and that aren't intimidated by the complexity of knowledge or by the organizational hierarchy.

From these two revolutions, informational and social, necessarily follows a revolution of organization. It is therefore imperative to have new practices which rebalance the traditional organizational model, focused on research of productivity, by a complementary model focusing on collaboration and innovation. Thus, this new model should ensure that organizations adopt innovation as an electric current pulses through every activity, that they deserve the

Manuscript received April 25, 2014; revised July 12, 2014.

The authors are with the Learning and Research in Mobile Age (LeRMA), National High School for Computer Science and Systems Analysis (ENSIAS), University Mohammed V - Souissi (UM5S), Rabat, Morocco (e-mail: elbassitilamyaa@gmail.com, ajhoun@gmail.com). passion and the creativity of the folks who work there and that they naturally elicit the very best that people have to give [1]. These are examples of the do-or-die challenges that organizations must face if they hope to thrive in the tumultuous years ahead.

This conceptual paper tries to serve as starting point for future research. Here, we will discuss some features of the $21^{\text {st }}$ century organization that will lead to more questions than answers. So, we hope that it participates in the scientific debate around the "Organization 2.0" paradigm, its promises as well as its challenges.

The remainder of this paper is structured as follows. The next section presents the organization 2.0 model in the light of the traditional organization model and according to various aspects and dimensions. The most critical challenges facing the organization 2.0 are discussed in the third Section. The following section studies three modern-day pioneers, rich of lessons that offer tracks for thought to the candidates of organizational renewal. Section $\mathrm{V}$ describes design features of the organization 2.0. The paper concludes with a summary and discussion of key directions for future research.

\section{New ORganizational Model}

"Organization 2.0" or "Enterprise 2.0" is currently amongst the fastest growing terms within the management literature. More than a fad, this new term presents a real radical change in the way to approach organization management. If related writings in the academic world are numerous, there are even more in the business literature. In 2006, Mcafee was the first to formalize this term in his article "Enterprise 2.0: The Dawn of Emergent Collaboration" [2]. However, this term is not yet explained theoretically and deserves more clarification.

An organization being identified as a social arrangement of values and beliefs can be defined by its design, governance, structure, process, coordination and management modes. From these dimensions, the promises of the organization 2.0 will be in a better management of skills, new interactions fostering collaboration, learning and innovation, new proximity to its ecosystem (especially its customers), better optimization of process and opening new deposit values.

Compared with the traditional model of organization, the organization 2.0 model would rely primarily on four elements to shape experience -knowledge, technology, people and organizational context. These elements, when used together and seamlessly connected, would support the emergence of vibrant communities that can exchange and effectively use the full range of data, information, knowledge and wisdom, help workers excel, enhance organizational performance and empower innovation.

The figure below depicts how these key elements 
-knowledge, technology, people and organizational contextwere related in the traditional organization model and how they should be in the organization 2.0 model.

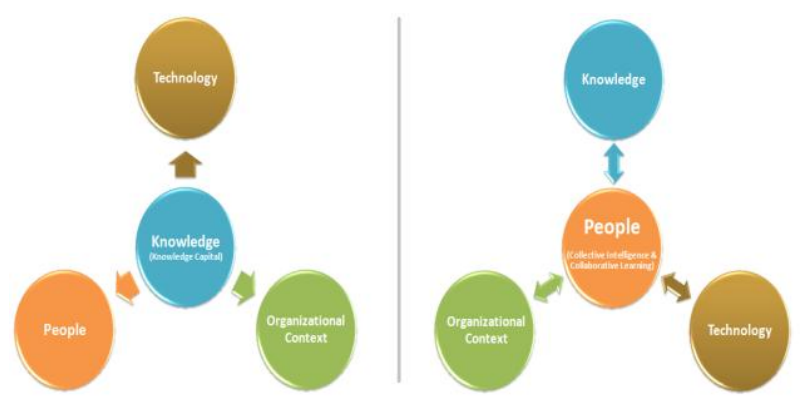

Fig. 1. Traditional organization vs organization 2.0.

TABLE I: ORGANIZATIONAL COMPARISON: INFORMATION AND KNOWLEDGE

\begin{tabular}{ll}
\hline \hline Traditional Organization & Organization 2.0 \\
\hline $\begin{array}{l}\text { Programmed } \\
\text { information-based } \\
\text { collaboration }\end{array}$ & $\begin{array}{l}\text { Emergent and open knowledge-based } \\
\text { collaboration }\end{array}$ \\
Information capital & Collaboration capital \\
Knowledge capital & Social capital \\
Local access to information & Global/Live access to information \\
Expert knowledge & Any knowledge from any individual \\
Individual intelligence & Collective intelligence \\
Generated by professionals & Generated by users themselves \\
\hline \hline
\end{tabular}

TABLE II: ORGANIZATIONAL COMPARISON: TECHNOLOGY

\begin{tabular}{ll}
\hline \hline Traditional Organization & Organization 2.0 \\
\hline Task oriented tools & User-centered tools \\
Overly complex tools & Easy to install and use tools \\
Rigid tools & Flexible tools \\
Passive usage with a static & Participatory and customizable usage with \\
content & a dynamic content \\
Developed by & Developed by users themselves \\
professionals & \\
Dedicated technologies & Collaboration IT-based features embedded \\
Casual use & in technologies \\
Professional use & Intensive and embedded use \\
\hline
\end{tabular}

TABLE III: ORGANIZATIONAL COMPARISON: PEOPLE

\begin{tabular}{ll}
\hline \hline Traditional Organization & Organization 2.0 \\
\hline Knowledge User & Knowledge Generator \\
Individual action & Social participation \\
One-to-many & Many-to-many \\
Reactive & Proactive \\
Production skills & Social and collaboration skills \\
Task completion & Purpose sharing \\
Authoritarian environment & Collaborative environment \\
Project manager & Facilitator \\
& (Champion/coordinator/animator) \\
Limited/Restricted access to & Organized/Unlimited access to the plan \\
the plan & \\
Limited communications & Unlimited communications \\
Project teams - inclusive & Open teams - progressive \\
& Virtual teams/communities \\
\hline \hline
\end{tabular}

The traditional organization model was very much structured and centered on information and knowledge. The manager was at the helm of business and controlled everything in the organization. Information and knowledge was largely concentrated at the top with limited sharing basis.
Power was delegated to managers alone. The purpose of work was simply accumulation of wealth and social status. Work conflicts from employees were most times disruptive and intolerable, whilst division of labor was the sole decision of managers with employees considered as executive robots. This model, seeming out of touch, must give way to another model, centered on creative people that will redesign the work structures and relationships to meet the changing variables and turn them to the organization's competitive advantage.

Gratton talks about this new organizational model in her book "The Democratic Enterprise" [3]. She states that through the forces of globalization, competition and more demanding customers, the structure of many companies has become flatter, less hierarchical, more fluid and virtual. The breakdown of hierarchies, she said, will allow organization 2.0 to have a fertile ground on which to create a more democratic way of working. A major study entitled "Management Futures", conducted by the Chartered Management Institute, which included a survey of 1,000 senior executives, on how organizations will look in 2018 [4] revealed that organizations will need technology that is able to capture and analyze implicit and tacit knowledge and allow the sharing of knowledge with customers and partners. The working population will be more diverse. Changing expectations of work and the impact of new technologies will require managers and leaders to develop a range of skills that focus on emotional and spiritual intelligence, judgment and the ability to stimulate creative thinking to improve productivity. Organizations will have to address the growing power of the employee and the need for personalized working patterns and benefits.

TABLE IV: ORGANIZATIONAL COMPARISON: ORGANIZATIONAL CONTEXT

\begin{tabular}{|c|c|}
\hline Traditional Organization & Organization 2.0 \\
\hline Control & Self-organizing \\
\hline & Communication and empowerment \\
\hline Production culture & Innovation culture \\
\hline Individualization & Socialization \\
\hline Hierarchy & Network \\
\hline Vertical organization & Horizontal/Flat organization \\
\hline Bureaucracy & Agility \\
\hline Information-centric & People-centric \\
\hline Implied structure & Emergent structure \\
\hline Centralization of control & Distribution of control \\
\hline Separate projects & Holistic approach \\
\hline Project management & Network and community animation \\
\hline Top-Down planning & Bottom-up planning \\
\hline Scheduled actions & On demand actions \\
\hline Standardization & Adoption/Emergence \\
\hline Structured - modeled process & Freeform - Ad-hoc process \\
\hline Prescriptive in nature & Emergent in nature \\
\hline Precise / predefined boundaries & Fuzzy/open boundaries \\
\hline Production driven process & Collaboration driven process \\
\hline Task oriented & Socio-emotional oriented \\
\hline Siloed and opaque organization & Open and transparent organization \\
\hline
\end{tabular}

A comparison between the traditional model of organization and the organization 2.0 model, according to the 
four aspects: information and knowledge, technology, people and organizational context, is summarized in Table I to Table IV.

According to Gary Hamel [1], traditional organizations have wrestled with a lot of burly problems to the ground. They have succeeded in breaking complex tasks into small, repeatable steps, in enforcing conformance to standard operating procedures, in figuring out how to measure costs and profits to the penny, in coordinating the efforts of tens of thousands of employees, and in synchronizing operations on a global scale. But these successes have come at a heavy price and the traditional model of organization has and continues to squander prodigious quantities of human imagination and initiative. It brought discipline to operations, but imperiled adaptability. It helped to multiply the purchasing power of consumers over the world, but enslaved millions of people in quasi-feudal, top-down organizations. It overcame the challenge of productivity, maximize efficiency and operational reliability especially with a large workforce, but it apparently hasn't strengthened their moral sense.

\section{Challenges of the Organization 2.0 MODEL}

In a turbulent environment, future organization must be endowed with an excellent ability to adapt. To be able to adapt, organization must be innovative and attractive. To success with innovation, organization must involve everyone in the collective creativity and collaborative learning effort. To have a fully engaged staff, organization must infuse its employees with a quite bold mission justifying extraordinary contributions and provide them an organizational climate conducive to mobilization. Those are the main challenges facing all organizations that aim sustainable advantage through the organization 2.0 paradigm. These five challenges shown in the following figure will be further discussed below.

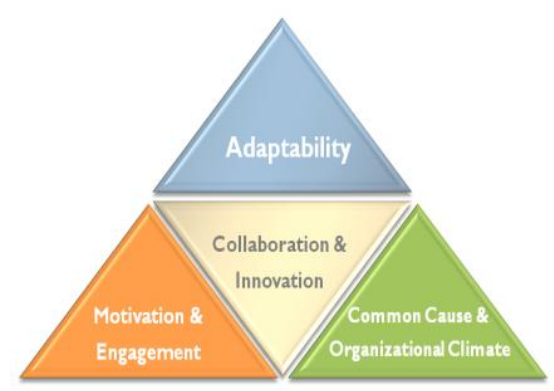

Fig. 2. Organization 2.0 Challenges.

1) Adaptability: How organizations could be adaptable, flexible and able to respond to change?

2) Innovation and Collaboration: How to involve everyone in the collective creativity and collaborative learning effort of organization?

3) Motivation and Engagement: How organizations could be fertile ground, where everyone gives the best of himself?

4) Common Cause: How to define a mission quite exciting justifying extraordinary contributions?

5) Organizational climate: How to provide an organizational climate that supports creativity, collaboration and learning among individuals in order to foster innovation?

\section{A. Adaptability}

Over the coming decades, the adaptability of every society, organization and individual will be tested as never been before. Luckily the perturbations create challenges as well as opportunities and the balance of promise and peril for any organization will depend on its capacity of adaptation. So, the organization 2.0 must deal with this challenge and provide adequate responses to the following question: How to get organizations capable of continual and trauma-free renewal?

By analogy, the next tumultuous years require organizations adaptable as the body's autonomic nervous system which allows quick, automatic, spontaneous and reflexive decisions making and actions taking. For example, when we step on a treadmill and we start jogging quickly and automatically, our heart rate and the blood flow to our muscles are increased; when we stand up and speak in front of an audience, spontaneously, our adrenal glands pump out hormones that accelerate our heart, respiratory rate and blood pressure in order to heighten our faculties; and when we look at a beautiful landscape - as Chefchaouen, the blue city in northern Morocco, especially its old medina, its waterfalls or its mountains - reflexively, our pupils are dilated, allowing us to better see the pleasant landscape.

Therefore, organization's survival will depend on the daily reproduction of routines and competencies in order to keep organizational resource exchanges, at least, in balance. Organizational survival will also rely on the availability of enough internal flexibility allowing the organization to cope with uncertainty.

\section{B. Innovation and Collaboration}

In a world where strategy life cycles are shrinking, only the collaborative innovation is allowing organizations to renew their lease on success. Collaborative innovation is also the only way enabling organizations to survive in a world of aggressive competition.

In the past, organizations have often protected their innovations from the fierce winds of competition by regulatory barriers, patent protection, distribution monopolies, disempowered customers, proprietary standards, scale advantages and capital hurdles. Hence, the second challenge that organization 2.0 must overcome is to provide practical answers to the following question: How to involve everyone in the innovation process, give them the needed creativity-boosting tools and allow them the required resources?

Inspired from the most successful markets' principles, such as Silicon Valley, the organization 2.0 must adopt collaborative innovation, or even open innovation, as a strategic objective and should liberate individuals to seek the best returns on investment in order to succeed the art of connecting the right resources to the right people at the right time.

\section{Motivation and Engagement}

As reported by one of the participants on the TECHTOC TV mission on the topic "philosophy of 2.0", all participants 
agreed that the best way for an organization to advance its goals, is to motivate its employees. As we know, voluntarily invest in a project is thousand times more valuable than results of an assigned mission. So organizations should take into account the clear difference between the motivation of an employee who is engaged and another who is assigned to a position. Therefore, the performance of an organization is closely linked to the motivation of its employees which in turn is influenced by their degree of empowerment, their development opportunities and their day-to-day satisfaction in their working environment.

A 2005 Towers Perrin study [5] of 86,000 employees working full time for large and midsize organizations in 16 countries across four continents, revealed that only $14 \%$ of all employees worldwide are fully engaged on the job, willing and able to give sustained discretionary effort to help their organizations succeed. The majority of employees in the study are moderately engaged and nearly a quarter of them reflected that they were actively disengaged. A recently Global Workforce study by global HR consultant Towers Watson in 2012 [6] found that almost two-thirds (63\%) of U.S. workers are not fully engaged in their work. So, it is a scandalous waste of human capacity, which explains why so many organizations are less able than people who work there. In past years, it might have been possible to ignore this incongruity, but no longer-not in a world where adaptability, collaboration and innovation have become the sine qua non of competitive success.

Daniel Pink in his book "Drive, the surprising truth that motivates us" [7] states that policies of "carrot and stick" cannot be considered as determinative of what can mobilizes or not employees to the success of their organization. So, motivate people only with money is no longer the most effective way and is even dangerous, as Enron shareholders discovered [8], especially when cupidity outweighs noble ambitions. So, in the absence of a generous ideal, temptation to transgress ethics bounds to ensure a personal gain is sometimes irresistible.

For Didier Pitelet, employees' commitment towards their organization must be earned and cannot be decreed. Hence, the challenge that organization 2.0 must face is to provide new answers to the following question: How to inspire employees to bring all of their capabilities to work every day, and give them opportunity to contribute to collective success?

The way in which democratic systems should work can be a good inspiration source, because the quality of a democracy depends on the commitment of its citizens and its strength depends not only on its leader. In a democracy, the pace of change depends only marginally on vision and moral courage of those in power. Industry groups, advocates of great social causes, think tanks and ordinary citizens can all influence legislative work and political priorities. The legitimacy that democracy gives militants is based on belief that every citizen has right to be a policy innovator. It also reflects a deep trust in voters' ability to wisely choose among many policy options, which at any time, compete to get their votes. Thus, democracy processes allow exploiting daily genius of ordinary people.

As reported by Winston Churchill "Democracy is a bad system, but it is the least bad of all systems" he known, because it is often paralyzed by conflicts of interest, while the need of organizations is rather to promote the convergence of interests. But despite all criticism, democracy remains a system that has a good capacity of adaptation and evolution. Francis Fukuyama describes democracy as "a set of accountability mechanisms. "So, in a democracy the power is subscribed in a vertical movement bottom up while the responsibility falls the same vertical axis, but in reverse. Therefore, politicians are elected by their constituents and are accountable to them. That is why they must take a wide variety of perspectives into account.

In practice, this means that organizations must conclusively and sustainably increase their employees' commitment.

\section{Common Cause and Resilience}

Even stronger than the need to contribute, is the need to belong to a group. From the personal meaning ${ }^{1}$ point of view, Digital Natives are young workers who wish to join colleagues who share a common cause. They want to feel that other people work along the same lines as they do. They want to join a cause that makes sense and doing fair business is part of their values and needs. From the organizational membership point of view, each employee basically expects that organization promotes links with and among its members. So, when managers and employees share the same ideology and values, collective and personal identity is built and this stimulates the mobilization.

Many organizations believe that employees pursue no higher purpose than "making the quarter", a partly incentive for the kind of imagination and courage required to drive continuous strategic renewal [1]. Whereas, the turbulent times we are living in need a big personal resilience which in turn require a shared sense of destiny, a goal that pulls everyone forward, a polar star which keeps references when everything changes around us. Thus, the organization 2.0 have to provide a courageous and ambitious answers to the following question: How to infuse the organization with the sense of a quite bold mission, to be able to successfully gather brains who get off on solving problems that are as important as they are seemingly intractable?

Religious faith seems to be the most appropriate analogy here, because Humans always seek guidance and direction in noble causes such religious faith, as it gives meaning to the human life and contributes to strengthen the resilience of believers. History offers countless examples from individuals whose serene faith, asserting the meaning of life, incite them to virtue, charity and righteousness ... Until prophets -Peace and Blessing Upon Them- and companions who found in the sacred mission they felt, courage to endure the worst hardships and tragedies and strength to accomplish extraordinary achievements. Moreover, the researchers found at many times that religious faith improve self-esteem, physical health, and ability to withstand life's traumas. This is why the meaning is an important design rule to create organizations capable of adapting to change.

\footnotetext{
${ }^{1}$ The term "personal meaning" refers to the way in which individuals subjectively perceive and explain their experiences, actions and social environments.
} 
Therefore, the organization 2.0 should think in a quite enthusiastic mission to outweigh the attraction power of the past and stimulate individual renewal.

\section{E. Ethics and Organizational Climate}

Generally, people are associated with groups that share the same values they do. These values are not dictated by the organization they belong, but they are intrinsic to each one of them. In his book Mobilization of people at work [9], Michel Tremblay makes distinction between "productivist" values such as efficiency, economy, effort, yield, etc. and "humanist" values such as collaboration, trust, initiative, justice, respect, etc. According to him, the mobilization needs and feeds, above all from humanistic values.

The state of accumulated scientific knowledge to date, as well the different reflections and research works, lead to conclude that a successful and stable mobilization requires building and sustaining a collective climate founded on a set of psychological states, namely brotherhood, justice, transparency, trust, freedom, support, recognition, etc. Such psychological climate might encourage individuals and groups to set high goals and persist in achieving them. And these positive psychological states will help to create enthusiasm and excitement, a dose of energy and motivation more favorable to the emergence of mobilization behaviors [10]. So, the challenge to be tackled by the organization 2.0 is to answer the following question: How to provide to its employees an organizational climate conducive to mobilization, collaboration and innovation?

At this level, we believe that successful military regimes that have a long-term advantage can provide a good analogy. So, in war as in business, most victories are pyrrhic and temporary. But in the pages of history, we can observe some military regimes that have consistently dominated their enemies, often despite a lack of men and equipment. This long-term military advantage, which is due neither to superiority of arms nor to brilliant command, explain Knox and Murray [1], result of fundamental advances in doctrine and military organization. On other side, armies and fleets more often victorious in the history are those who succeeded to break with the past and to imagine new ways to motivate, control, develop and deploy fighters. Alberts and Hayes, working on this doctrine in the US Department of Defense, estimate that the basic principle is self-synchronization of forces [11]. So, to ensure agility in combat and speed of execution, forces must be able to act independently from the available information and without waiting for higher orders. They must, however, permanently inform other units and the hierarchy of their observations and intentions. In such system, the chain of command does not send orders, but cons-orders, particularly when it has new information that forces on the theater of operations does not have [11].

In practice, to support self-synchronization in organization 2.0, four conditions must be fulfilled:

1) As soldiers, employees must have a clear and consistent understanding of the intent and direction of the organization strategy.

2) Organization 2.0 must ensure the exchange of high quality information so that everyone has a shared appreciation of the current situation.
3) Organization 2.0 must assist its employees to have a high level of skill, through intense training and workout activities.

4) Employees must have trust in information, the organizational context and their colleagues.

Hence, building an organizational climate conducive to mobilization and innovation must be an everyday concern of organization 2.0.

\section{TYPICAL ORGANIZATIONS}

Below we will study three pioneers, organizations that have been wrestling with the above seemingly intractable challenges and that have making real progress. Google that has developed an organizational model that places adaptability above all else, WL Gore that has been labeled the world's most innovative company and that was one of the weirdest most effective organizations on the globe and Whole Foods with its sellers more enthusiastic and more motivated than any other distribution groups.

\section{A. Google}

TABLE V: LEARNED LESSONS FROM GOOGLE SUCCESS

\begin{tabular}{ll}
\hline \hline Challenge & Lessons \\
\hline \multirow{2}{*}{ Adaptability } & - Open up the strategy process. \\
& - Rely on a myriad of small autonomous, \\
& - Encopendent and agile teams. \\
& - Give employees time (20\% rule) and minimize the \\
& number of approval levels. \\
& - Emphasize test and learn instead of plan and \\
Innovation \& & execute. \\
Collaboration & - Offer outsized rewards for those who come up \\
& with game-changing ideas.
\end{tabular}

Common Cause \& "Organize all information in the world to build Resilience better world."

- Consultative decision making: those affected by a decision have the right to participate directly in the process and not be agreeing.

Motivation \& - Employees free to wisely, say what they think, on Engagement anything, to anyone and expect to be taken seriously.

- Adopt the principle that an employee not need to be in a start-up to make fortune (Founders Awards).

- Lead company as a wide area of discussion: every week, up to six hours devoted to dialogue with members of various teams.

Ethics \& - Adopt and keep a flat hierarchy: Checking in Organizational peer-to-peer, not from managers to subordinate. climate - Management mode based on collective genius, openness, transparency and a lot of lateral communication.

Google as an amazing success story was founded by Larry Page and Sergey Brin, two Stanford University graduate students in computer science Ph.D. program, less than two decade ago. The two graduate students had collaborated on a project that aims to crawl the web to discover which sites 
linked to a specific webpage. This project gave birth to an algorithm that delivered a quantum leap in Web-search performance. After, Google's eponymous service has grew as fast as the web itself, mainly when Google has found a magic elixir that turned all users clicks into cash by mixing search with advertising and since, the income from letting companies bid for ads that appeared when users typed in specific keywords became Google's economic engine. Google's revenue numbers continued to climb from $\$ 3.2$ billion in 2004 to $\$ 16.6$ billion in 2007, $\$ 29.3$ billion in 2010 , then to $\$ 37.9$ billion in 2011. Google has closed 2012 with $\$ 50.2$ billion in annual revenue and the Google brand is now the highest ranked brand in the world.

Google's success to date offers valuable lessons, we have summarized in Table V.

Google has been ranked number one on FORTUNE's list of "100 Best Companies to Work For" in 2007, 2008 and every year since 2012 .

\section{B. W. L. Gore}

After a 17-year career as a research supervisor and head of operations research, Wilbert Gore, called Bill by everyone, that holds a master of science in physical chemistry from the University of Utah, left DuPont de Nemours to strike out on his own. After successfully made a PTFE-coated ribbon cable in his home basement laboratory, Bill Gore tried to persuade DuPont to adopt his invention as a new product, but DuPont wanted to remain a supplier of raw materials and not a fabricator and since, Bill dreamed of building a company devoted to innovation, a company where imagination and initiative would flourish, where chronically curious engineers would be free to invent, invest, and succeed. On January 1,1958 , their $23^{\text {rd }}$ wedding anniversary, Bill and his wife founded W. L. Gore \& Associates, an organization that has become a modern-day success story as a uniquely-managed family business. W. L. Gore continued to grow and develop new products primarily derived from PTFE, including its best-known product Gore-Tex. Today, W.L. Gore generates more than $\$ 3$ billion in annual sales and employs more than 10,000 employees (called associates) at more than 50 facilities throughout the world.

From this innovative structure we can learn the following lessons (Table VI).

W. L. Gore \& Associates has delivered more than 50 years of steady earnings growth without a single annual loss. So, it seems unlikely that Bill Gore, who died in 1968, would be surprised by his company's continuing success. For the $17^{\text {th }}$ consecutive year, W. L. Gore earned a position on FORTUNE's annual list of the U.S. "100 Best Companies to Work For" and in 2014 W. L. Gore ranked $22^{\text {nd }}$ overall. W. L. Gore is one of only a few companies to appear on all of the U.S. FORTUNE's lists since 1984.

\section{Whole Foods}

From the fairly humble beginning of being a one-store entrepreneur living on the third floor, John Mackey has seen his 1978 Safer Way grocery store grow into the world's leading natural and organic food supermarket. Through a long series of acquisitions, John Mackey has created a niche retailer which enjoys lofty profits in a very price competitive industry that is typically characterized by accordingly low profit margins. The Whole Foods Market's motto "Whole Foods, Whole People, Whole Planet" emphasizes the company's vision as more than just a food retailer. Whole Foods Market is heavily involved in environmental issues and community involvement. They donate at least $5 \%$ of their net profits yearly to charitable causes. Whole Foods made the U. S Environmental Protection Agency's list of the "Top 25 Green Power Partners" with such efforts as: eliminating plastic, working to ensure the humane treatment of animals, protection of the fishing industry, and offsetting its energy costs through wind power credits. This largest natural and organic food chain employs today more than 80,000 team members, operates 373 stores and had sales of approximately $\$ 13$ billion in 2013. It is also the America's most profitable food retailer when measured by profit per square foot.

TABLE VI: LEARNED LESSONS FROM W. L. GORE SUCCESS

\begin{tabular}{|c|c|}
\hline Challenge & Lessons \\
\hline Adaptability & $\begin{array}{l}\text { - Flat Hierarchy, no hierarchical level and no } \\
\text { organizational chart. } \\
\text { - Key entities are small self-managed teams. } \\
\text { - No core business. }\end{array}$ \\
\hline $\begin{array}{l}\text { Innovation \& } \\
\text { Collaboration }\end{array}$ & $\begin{array}{l}\text { - Ever repeat that innovation can sprout in the } \\
\text { minds of anyone. } \\
\text { - Reserve } 10 \% \text { of employee's time (half day per } \\
\text { week) to "out-of-scope" projects. } \\
\text { - Don't make management approval a prerequisite } \\
\text { for initiating new projects. }\end{array}$ \\
\hline $\begin{array}{l}\text { Common } \\
\text { Cause \& } \\
\text { Resilience }\end{array}$ & "Innovate, enjoy and succeed". \\
\hline $\begin{array}{l}\text { Motivation \& } \\
\text { Engagement }\end{array}$ & $\begin{array}{l}\text { - Voluntary Commitment: employees negotiate } \\
\text { assignments and responsibilities with their peers. } \\
\text { - Employees are evaluated and compensated } \\
\text { according their contribution to the success of the } \\
\text { team. } \\
\text { - Tasks can't be affected, they can only be } \\
\text { accepted. } \\
\text { - One who provides an outsized contribution } \\
\text { becomes leader. }\end{array}$ \\
\hline $\begin{array}{l}\text { Ethics \& } \\
\text { Organizational } \\
\text { climate }\end{array}$ & $\begin{array}{l}\text { - Lattice Management: dense network of } \\
\text { interpersonal connections where information can } \\
\text { flow in all directions, unfiltered by an } \\
\text { intermediary. } \\
\text { - Sponsors to help newcomers find a good match } \\
\text { between their talents and the needs of this or that } \\
\text { team. } \\
\text { - Create a sense of solidarity (all employees are } \\
\text { shareholders). } \\
\text { - Atmosphere of intimacy encouraging dense } \\
\text { cross-functional and cross-team communication. }\end{array}$ \\
\hline
\end{tabular}

From this iconoclastic pioneer we can learn the following lessons:

Whole Foods Market has been ranked on Fortune Magazine's “100 Best Companies to Work For" every year since the list's inception in 1996. In the Wall Street Journal/Harris Interactive ranking of the world's best and worst corporate reputations, Whole Foods placed $12^{\text {th }}$ overall and received the best score of any company for social responsibility. They were recently rated as the number one 
“Green Brand" with Digital Natives. In 2007, Whole Foods was voted as the fifth most rewarding place to work in America.

TABLE VII: LEARNED LESSONS FROM WHOLE FOODS SUCCESS

\begin{tabular}{|c|c|}
\hline Challenge & Lessons \\
\hline Adaptability & $\begin{array}{l}\text { - Adopt a radical spirit of decentralization. } \\
\text { - The basic entities are autonomous and small teams } \\
\text { responsible of all key business decisions (pricing, } \\
\text { ordering, hiring, promotions ...). } \\
\text { - Provide employees much sensitive information. }\end{array}$ \\
\hline $\begin{array}{l}\text { Innovation \& } \\
\text { Collaboration }\end{array}$ & $\begin{array}{l}\text { - Practice a management without secret. } \\
\text { - Each team attempts to improve its own record to } \\
\text { outperform other teams. } \\
\text { - Success translates directly into recognition, } \\
\text { bonuses and promotions. }\end{array}$ \\
\hline $\begin{array}{l}\text { Common } \\
\text { Cause \& } \\
\text { Resilience }\end{array}$ & "Wole Foods, Wole People, Wole Planet" \\
\hline $\begin{array}{l}\text { Motivation \& } \\
\text { Engagement }\end{array}$ & $\begin{array}{l}\text { - Give employees a large dose of discretion. } \\
\text { - Believes that interests of various stakeholders are } \\
\text { interdependent. "Declaration of interdependence" } \\
\text { considered as the company's mission statement: } \\
\text { "Community whose members work together to } \\
\text { create value for others". } \\
\text { - Hold them accountable for results. }\end{array}$ \\
\hline $\begin{array}{l}\text { Ethics \& } \\
\text { Organizationa } \\
1 \text { climate }\end{array}$ & $\begin{array}{l}\text { - Create a high level financial transparency } \\
\text { (everyone can know at any time the wages of } \\
\text { others). } \\
\text { - Limit the wage gaps (Managers refrain from } \\
\text { winning more than } 19 \text { times the average wage and } \\
93 \% \text { of the stock options of the company are } \\
\text { assigned to non-executives.) } \\
\text { - Translate noble principals in management } \\
\text { practices. }\end{array}$ \\
\hline
\end{tabular}

\section{DESIGN FEATURES OF ORGANIZATION 2.0}

The organization 2.0 model would rely on four key cornerstones, which are knowledge, technology, people and organizational context, to ensure sustain advantage. These cornerstones, when used together and seamlessly connected, would support effective management of collective intelligence and collaborative learning in order to foster innovation.

\section{A. Knowledge}

Given that innovation is the key drivers of competitive advantage, growth and profitability of today's organization, knowledge, as catalyst and vehicle for increasing innovation and hence competitiveness, have also become an important strategic resource for organizations. To know who works with whom, on which projects, with which customers and on what research areas is an important step towards the understanding of intra or extra-organizational relationships. To support effective innovation management, organizations must adopt a knowledge management approach that can integrate dispersed resources into a coherent corpus of interrelated information.

Therefore, organization 2.0, that seeks competitive advantages, high performance level, to face the challenges of the actual society, to innovate and to have the capacity to adapt quickly, must establish an effective knowledge management model within which the principles of innovation and collaboration can be incorporated. So, the knowledge generation should not be limited to experts but should include the social production of knowledge. The constructed knowledge must be embodied within the organization through a process of social interchange and the embodied knowledge must be disseminated throughout the organization. The use and benefits of knowledge management must consider both business and employee benefits.

\section{B. Technology}

Social and web 2.0 technologies can be a powerful lure for an organization, their interactivity promises to bring more employees into daily contact at lower cost. When used effectively, they also may encourage participation in projects and idea sharing, thus deepening a company's pool of knowledge. They may bring greater scope and scale to organizations as well, strengthening bonds with customers and improving communications with suppliers and outside partners.

The advent of social and web 2.0 technologies has led to new usages of information, knowledge sharing culture, new practices and new behaviors. According to 2009 McKinsey Quarterly survey [12] of nearly 1700 executives from around the world, across a range of industries and functional, about the business benefits their organizations have gained as a result of using web 2.0 technologies, $69 \%$ of respondents report greater ability to share ideas, improved access to knowledge experts, and reduced costs of communications, travel and operations. Many respondents also say that web 2.0 tools have decreased the time to market for products and have had the effect of improving employee satisfaction. The survey found also that successful companies not only tightly integrate web 2.0 technologies with the work flows of their employees but also create a networked company, linking themselves with customers and suppliers through the use of web 2.0 tools.

So, in order to enjoy benefits from social and web 2.0 technologies, organization 2.0 requires that the use of these tools be integrated into the flow of users' work. Furthermore, to encourage continuing use, organization 2.0 requires approaches other than the traditional financial or performance incentives deployed as motivational tools.

\section{People}

It is often said that without ideas or rather without good ideas, there are few chances to have an innovation that can drive growth of organization, further, an innovative idea without a champion gets nowhere. People as key ingredient to organizational success and failure [13], and by all accounts increasingly important, has become the organization 2.0 most vital resource.

To ensure a sustain advantage, organization 2.0 strive to attract new members and encourage them to create, collaborate and contribute to collective intelligence and collaborative learning activities based on knowledge production. However, the knowledge per se does not assure the success of the organization 2.0. It is the collaborative 
efforts made by people to manage the knowledge, to enrich the organizational memory and to help each other accumulate their knowledge in their domain of interest that is central to the continuous growth of such organization. So, when an innovative idea is expressed to others, it proliferates into multiple ideas because people have diverse skills, energy levels, frames of reference and interpretive schemas as a result of their back-grounds, experiences, and activities that occupy their attention and that filter their perceptions. These differing perceptions and frames of reference are amplified by the proliferation of transactions and relationships among people and organizational units that occur, as the innovation unfolds. Moreover, motivated and fully engaged teams usually accomplish much more than individuals can do.

Hence, organization 2.0 must figure out a way to coordinate the efforts of thousands of individuals without creating a burdensome hierarchy of overseers, to keep a tight rein on costs without strangling human creativity, to build organizations where discipline and freedom aren't mutually exclusive, organizations endowed with an excellent ability to adapt and completely human.

\section{Organizational Context}

Clegg \& al. state that $90 \%$ of IT projects fail to meet their goals due to a misalignment of goals and organizational activities [14]. Thus, all effort that is not in line with the organization context (strategy, goals and needs, resources and culture, structure and processes, etc.) may fail. According to Griffin, the most successful organizations do not succeed merely by using one innovation approach more extensively or better, but by carefully selecting the right approach within a given context [15]. So, a contextual approach of management can provide an overview of alternative choices in different contexts and assist people in their decision-making process, which in turn will make organization 2.0 processes more efficient. Nevertheless, people must have the freedom to make these adaptations and not be limited by corporate rules that contradict what their specific context demands.

Thus, organization 2.0 must encourage individuals and groups to set high goals, while ensuring their alignment with the organizational context, and to persist in achieving them. Organization 2.0 would be one that supports workspace freedom, accessibility and flexibility to give its employees ample conditions to innovate, develop and be useful. It should therefore, that collective work climate becomes its daily concern to infuse positive energy, enhance commitment and ensure employees full engagement and mobilization.

\section{CONCLUSION}

It is our strong believe that organization 2.0, whatever the name that will be retained in the field of research, isn't a buzzword or related to a passing 2.0 fashion, but is a real future organizational transformation. Organization 2.0, as the novel model of organization for the new collaboration and innovation era, will certainly leverage from the collective intelligence, the sharing and co-creation of knowledge, the consolidation of capital and the acceleration of innovation. But it also presents several challenges, because this novel organizational model requires considering the cultural diversity both at managerial and technical level, ensuring that innovation becomes a major concern in organization, that collective genius will bear on all decisions and this requires openness, transparency, devotion, justice, freedom, compassion, etc. The organization 2.0 model further requires the reinvention of traditional management towards another that twines democracy with discipline, confidence with responsibility and community spirit with fierce competition. Those are the imperatives that drove men to extraordinary achievements over centuries and these counterpoised values that will make the company's new management system more effective.

Talking about innovation, is also talking about ideas, about creativity and about invention, but equally about the process that transform ideas into new or improved products. This process, based essentially on the generation of new concepts, is rarely the work of one single person but, on the contrary, the result of teamwork often multidisciplinary. It is precisely in this multidisciplinary context, at the interaction between technique and human, that we are particularly interested. Notably, we aim to define a generic framework to orchestrate collective intelligence and collaborative learning in order to foster innovation, based on emergent technologies that today focuse more on semantic web and other emerging approaches such as Open Innovation and Crowdsourcing.

\section{REFERENCES}

[1] G. Hamel and B. Breen, The Future of Management, Harvard Business School Press, September 2007.

[2] A. P. McAfee, "Enterprise 2.0: The dawn of emergent collaboration," MITSloan Management Review, vol. 47, no. 3, pp. 21-28, 2006.

[3] L. Gratton, The Democratic Enterprise, Financial Times Prentice Hall, 2004.

[4] Chartered Management Institute, Management Futures: The World in 2018, 2008.

[5] Towers Perrin HR Services, Winning Strategies for a Global Workforce, Attracting, Retaining and Engaging Employees for Competitive Advantage, Towers Perrin Global Workforce Study Executive Report, January 2006.

[6] Towers Watson, "Engagement at Risk: Driving Strong Performance in a Volatile Global Environment," Towers Watson Global Workforce Study, July 2012.

[7] D. H. Pink, Drive: The Surprising Truth about What Motivates Us, Riverhead Hardcover, December 2009.

[8] J. A. Petrick and R. F. Scherer, "The enron scandal and the neglect of management integrity capacity," American Journal of Business, vol. 18 , no. 1 , pp. 37-50, 2003.

[9] M. Tremblay, "La mobilisation des personnes au travail," Collection Racine du savoir, Gestion, 2006.

[10] M. Patterson, P. War, and M. West, "Organizational climate and company productivity: The role of employee affect and employee level," Journal of Occupational and Organizational Psychology, vol. 77, 2004.

[11] M. R. Dugages, Organisation 2.0: Le Knowledge Management Nouvelle Génération, Eyrolles, 2007.

[12] How companies are benefiting from Web 2.0, McKinsey Global Survey, June 2009.

[13] J. N. Baron and D. M. Kreps, Strategic Human Resources: Frameworks for General Managers, NY: Wiley, pp. 1-13, 1999.

[14] P. M. Bednar, "A contextual integration of individual and organizational learning perspectives as part of IS analysis," Informing Science, vol. 3, no. 3, pp. 145-156, 2000.

[15] A. Griffin, "PDMA research on new product development practices: updating trends and benchmarking best practices," JPIM, vol. 14, no. 6 , pp. 429-458, 1997.

L. EI Bassiti was born in Morocco on December 1, 1984. She was conferred the degree of computer science engineer from ENSIAS School. She is a 
Ph.D. student in the Center of Sciences in Information Technology and Engineer (CEDoc ST2I) at ENSIAS. She has been an expert engineer in Enterprise Content Management (ECM) and GroupWare (GW). She is a visiting professor in different School of Engineering. She has published articles about organization 2.0, innovation and idea management.

R. Ajhoun was born in Morocco. She got the computer science engineer degree from EMI School (Mohammadia School of Engineering), PhD degree in computer science and e-learning at University of Mohammed V. Prof. Ajhoun has published articles and books about e-learning and teaches at the
ENSIAS School. Prof. Ajhoun is a senior member of IEEE, director of the E-learning Center at University of Mohammed V, LeRMA research team and e-NGN (E-Next Generation Networks) association. She has founded the GUIDE (Global University In Distance Education) association. 